Cornell Law Library Scholarship@Cornell Law: A Digital Repository

$1-1-1996$

\title{
Constitutionalism in Zambia: Past, Present and Future
}

\author{
Muna Ndulo \\ Cornell Law School, mbn5@cornell.edu \\ Robert B. Kent \\ Cornell LawSchool, rbk5@cornell.edu
}

Follow this and additional works at: http://scholarship.law.cornell.edu/facpub

Part of the Constitutional Law Commons

\section{Recommended Citation}

Ndulo, Muna and Kent, Robert B., "Constitutionalism in Zambia: Past, Present and Future" (1996). Cornell Law Faculty Publications. Paper 64.

http://scholarship.law.cornell.edu/facpub/64 


\title{
GONSTITUTIONALISM IN ZAMBIA: PAST, PRESENT AND FUTURE
}

\author{
Muna B. Ndulo* and Robert B. Kent**
}

Writing about any constitution is tricky business and that of Zambia is no exception. Four constitutions in 32 years hardly represents a settled state of affairs, and an end, or even a stopping place of long duration, does not appear in sight. ${ }^{1}$ This is, however, an interesting, even exciting period in Zambia's brief constitutional history. The subject cries out for an examination of where the country has been, where it is, and where, at least in the opinion of these observers, it ought to be heading.

We are happy to undertake this brief assessment in the context of recognition of the career of Professor J.S. Read. This able, patient, effective, and thoughtful scholar has been a mentor to generations of African lawyers, including Zambians. To both of us Jim Read has been a warm and generous friend, from time to time a wise counsellor who has contributed much to our own efforts.

\section{Introdugtion: The Gharagteristigs of a Constitution}

In its broadest sense a constitution represents the basic structure of any organized society. Formal or informal, written or unwritten, its existence is inevitable. One may or may not be able to touch it as a document or to read it as a series of documents, but as societal structure it is there. When one speaks of a modern constitution, however, notions of formality emerge, and in post-colonial Africa this has come down to a single document, a charter for the exercise of political power called a constitution. Some have questioned the suitability of Western models for use in sub-Saharan Africa, but the impact of history seems clear; one may interpret or reinterpret history, but one cannot repeal it. As elsewhere, the basic assumption in Zambia is that there is and shall be a written constitution. Despite the frequency of constitutional changes, some common characteristics appear. Commitment to constitutional principles is expressed by political leaders, although the extent to which those principles are observed in action is open to serious debate.

With all the difficulties of definition and determination of detail, there is a stated commitment to democracy and to government with the consent of the governed. The aim of the constitution-making process is the achievement of a constitution that is legitimate, credible and enduring, that guarantees rights and freedoms perceived to be fundamental, and that provides a structure for the effective conduct of the nation's business, for the achievement of its economic development and for the

* Visiting Professor of Law, Cornell Law School.

** Professor of Law Emeritus, Cornell Law School.

${ }^{1}$ Since Zambia gained independence from Great Britain on 24 October, 1964, it has had the following Constitutions: 1964 Constitution provided for in Schedule 2 to the Zambia Independence Order, 1964, promulgated by Her Majesty in Council under the provisions of the Foreign Jurisdiction Act, 1890; The Constitution of Zambia Act, 1973; The Constitution of Zambia Act, 1991, and The Constitution of Zambia (Amendment) Act, 1996, which, even though it did not repeal the whole of the 1991 Constitution, introduced such significant changes as to render the resulting document a new Constitution. 
welfare of its citizens. Vital to such a constitution is the recognition of the essential condition of free elections at established intervals with the guarantee of full participation by all parts of the pluralistic society that is Zambia, in short a mechanism for the orderly transfer of political power. Vital also are the protection of human rights, an independent judiciary and the accountability of political leaders on the basis of openness, probity and honesty. ${ }^{2}$

The process of constitution-making is crucial. The constitution is no ordinary law to be modified or replaced by ordinary legislation. It must be perceived as a higher law, authorizing and governing ordinary law and commanding adherence to constitutional precepts. While ordinary law may be adopted and altered by legislative majorities of whatever size, the adoption of a constitution and its amendment requires much more, widespread participation by the citizenry and the achievement of a broad-based consensus. The process must take place in the full view of the country and the international community of which it is a part. ${ }^{3}$

It is submitted that the foregoing are widely accepted in principle. Their realization is another matter and the gap between articulated goals and their achievement is wide. There are many reasons for this, and they are worth exploring, most effectively, through an examination of the making, alteration and unmaking, of Zambia's constitutions since the achievement of independence and the foundation of the Republic in 1964. This examination is timely. Constitutional storm clouds have gathered in Zambia, and not for the first time. There is compelling evidence that the constitutional process is under great stress, that constitutional change has been effected without widespread participation of the people, and that the changes serve and are intended to serve the short-range political interests of those in power. ${ }^{4}$ This article focuses particularly upon the methodology of change and the extent to which that methodology has served the aspirations of democracy.

\section{The Golonial Period}

Since the advent of colonialism Zambian society has undergone profound economic, social and political change. From self-sufficient subsistence communities dependent on agriculture, Zambia has become dependent substantially upon a money economy and a capitalistic system. The security of communities once dependent upon various tribal organizations is now provided largely by a unitary government. What colonialism initiated independence has consummated, a disruption of tribal organization and tribal life and the unification of ethnic communities under the umbrella of one

2 See James C.N. Paul, "Developing constitutional orders in Sub Saharan Africa: an unofficial report", Third World Legal Studies, 1988, 1. In this article Professor Paul maps out the scope and content of developing constitutional order in Africa. See also Kwamena Bentsi-Enchill, "Civitas Dei Africana: realizing the African political dream", [1969] Zambia Law Joumal 65; and also S.A. de Smith, The New Commonwealth and its Constitutions, London, 1964.

3 Intemational Round Table on Democratic Constitutional Development, Commonwealth Secretariat, 1995, 22.

4 A recent report of the Commonwealth Human Rights Initiative which went to examine the political situation after the May 1996 amendments to the Constitution concluded: "The political situation in Zambia merits urgent attention from its friends and from the international community at large as a fragile experiment in democracy is under threat in a situation where the shortage of time is a critical factor", The Post, 24 September, 1996. 
sovereign state with overriding power over the entire country. ${ }^{5}$ The national coat of arms symbolizes this: "One Zambia, One Nation".

\section{A synopsis of colonial history}

Although European contact with what is now Zambia dates from the 15th century with the coming of Portuguese traders, the colonial period had its effective beginning with the 19th-century journeys of European explorers: missionaries, visionaries, adventurers. Through them Europe became aware and interested in Central Africa. ${ }^{6}$ Dr David Livingstone was the most important of these; he opened the way for the first Christian missionary settlements. ${ }^{7}$

In constitutional terms the first significant development was the charter incorporating the British South Africa Company and according it broad fiscal and administrative power in Central Africa. ${ }^{8}$ This was the product of pressure upon the British government from the missionaries on the one hand to put an end to the slave trade, and imperialists on the other, most significantly Gecil John Rhodes, ruler of a gold and diamond empire in Southern Africa. The missionaries wanted a protectorate; the British were reluctant to become directly involved. Rhodes wanted indicia of power in aid of the struggle with Portugal over trade and influence. The charter to Rhodes's company was the way out for the British government for over 30 years from its granting in 1889. Through African treaties and concessions obtained from African chiefs the Company extended its sway over most of what is now Zambia. ${ }^{9}$

Acquisition of power followed somewhat different routes in different parts of what is now Zambia, but by $1900^{10}$ British rule had been formalized by two orders, the North-Western Rhodesia-Barotseland Order-in-Council of 1899 and the NorthEastern Rhodesia Order-in-Council of 1900. Rhodes's name had been affixed by 1897. The territories were joined in 1911 as Northern Rhodesia. " Barotseland, however, enjoyed a different constitution position. In 1899 it was granted British protection on its conceding to the British South African Company a monopoly over mining and trading rights in the territory. ${ }^{12}$

5 K. Mann and R. Roberts (eds.), Law in Colonial Africa, London, 1991, 3-23 and J.B. Ojwang, "Rural settlement in Kenya", (1975-78) 7-10 Zambia Law Joumal, 63-83; and T. Nhlapo, "Accommodating traditional forms of governance", International Round Table on Democratic Constitutional Development, above, 168.

6 The Portuguese had by the 15th century established themselves on the east coast of Africa and carried on a gold trade particularly around Sofala. See E.V. Exelson, The Portuguese in South-East Africa 1600-1700, London, 1960 and A.J. Wills, An Introduction to the History of Central Africa, London, 1973.

7 H.M. Hole, The Making of Rhodesia, London, 1926.

8 Royal Charter of Incorporation of the British South Africa Company, 29 October, 1889. As originally drawn the Charter covered the area south of the Zambezi River. On 5 March, 1891, it was amended to include the area north of the Zambezi.

9 L.H. Gann, The Birth of a Plural Sociely: the Development of Northem Rhodesia under the British South Africa Company, 1894-1914, Manchester, 1958.

10 L.H. Gann, History of Northem Rhodesia: Early Days to 1953, London, 1964.

II Northern Rhodesia Proclamation No. 1 of 1911.

12 This was later reflected in the 1964 constitutional arrangements. At the time of independence Britain concluded what is known as the Barotse Agreement of 1964. The status of Barotseland has continued to be a matter of political dispute. See Report of the Constitutional Review, 1995, Chapter 29, 65. 
Company rule lasted until 1 February, $1924 .{ }^{13}$ The Order-in-Council of that year established colonial office rule under a Governor. The Central African Federation, comprising Northern Rhodesia, Southern Rhodesia and Nyasaland, came into being in $1953^{14}$ and was seen by the British as a means of disentanglement from direct responsibility. ${ }^{15}$ Viewed by Europeans as a step towards white settler control and the amalgamation of the three territories, the Federation only increased the growth of African nationalism, which caused its collapse in $1963 .{ }^{16}$ On 24 October, 1964, Northern Rhodesia became the independent Republic of Zambia. ${ }^{17}$

\section{The colonial "Constitutions"}

Until the very end of the colonial history of Northern Rhodesia democratic selfgovernment did not exist. In a meaningful sense there was no constitution other than that of Westminster. There was, however, a series of structural arrangements decreed by the British government, loosely termed "Constitutions". ${ }^{18}$ Enacted through Orders-in-Gouncil, these arrangements were designed to promote governance with the active co-operation of the white settlers and acceptance by the Africans, with such acceptance declining sharply, particularly during the period of the Federation. The flexibility of these "Constitutions" lay in the ease in which they could be amended in response to pressures and crises. ${ }^{19}$ Although limited African franchise appeared in 1958, becoming substantial in 1962, full suffrage only arrived in January 1964. The elections of that year brought an overwhelming victory for the United National Independence Party (UNIP) and the emergence of its leader, Kenneth David Kaunda, as the prime minister of the last Government of Northern Rhodesia. ${ }^{20}$

\section{The 1964 Independenge Constrtution}

The final Order-in-Gouncil came later in 1964 following negotiations in London in May. Accompanied by an Act of Independence by the British Parliament, the Order's Schedule II set forth the Constitution of Zambia. ${ }^{21}$ Chapter I is entitled "The Republic". Section 1 simply reads "Zambia is a sovereign Republic". The effective date is 24 October, $1964 .{ }^{22}$ Like its colonial forbears this 1964 document details the structure of government so minutely that it has about it the look of ordinary legislation, which being a constitution it is not. But with an exception to be discussed, it was a very flexible document, providing for its own amendment by processes similar to the enactment of ordinary legislation, even with its requirement

\footnotetext{
${ }_{13}$ Northern Rhodesia Order in Council, 1924.

14 Federation of Rhodesia and Nyasaland Order in Council, 1953.

15 A. Roberts, $A$ History of Zambia, London, 1976.

16 See R. Hall, Northem Rhodesia, London, 1964 and R.I. Rotberg, The Rise of Nationalism in Central Africa, Cambridge, 1965.

17 Zambia Independence Order, 1964, and Zambia Independence Act, 1964.

${ }^{18}$ The Northern Rhodesia Order in Council, 24 February, 1924, set up Legislative and Executive Councils; in 1959 a ministerial system was introduced; Northern Rhodesia Constitution promulgated on 11 December, 1962.

19 S. Mubako, "Zambia's single-party constitution-a search for unity and development", (1973) 5 Zambia Law Joumal, 67.

${ }_{20}$ Hall, above and J.M. Mwanakatwe, The End of the Kaunda Era, Lusaka, 1994.

21 See n. 17.

22 Constitution of Zambia, 1964.
} 
of a two-thirds majority. ${ }^{23}$ This sowed the seeds of future changes sufficiently frequent and drastic as to undermine a needed constitutional stability and to negate a broadlybased participation by citizens in the alteration of their fundamental law.

Commonly, independence constitutions in British Colonial Africa have borne the imprint of the Westminster model of representative parliamentary government. There are differences among them. In some a non-executive president substituted for the Queen as head of state. In others, including Zambia, the President became in addition the chief executive. The tri-partite structure had in some ways the look of Washington rather than Westminster, but its degree of detail reflected its colonial ancestry. The powers of the colonial Governor passed largely intact to the executive President.

Section 32 of the Constitution stated that "the first President shall be Kenneth David Kaunda". From this must not be drawn the inference that Kaunda was simply the hand-picked choice of British government. On the contrary, the final Constitution of Northern Rhodesia had conferred effective self-government upon the colony with an election machinery based on universal suffrage. The elevation of Kaunda to the post of Prime Minister was a result of his party's triumph at the polls. ${ }^{24}$ All political parties saw no need for another election later in the same year, and agreement was reached that the Independence Order should name him as the first President.

\section{The executive presidency}

The qualifications for the presidency were straightforward: Zambian citizenship, attainment of the age of 30 and qualification as a voter in elections to the National Assembly. ${ }^{25}$ Subsequent presidential elections were part of the process of election of members to the National Assembly. Every parliamentary candidate was required to declare which of the presidential candidates he or she supported. ${ }^{26}$ Every vote cast in favour of a parliamentary candidate was considered a vote for the candidate for the presidency which that parliamentary candidate supported. ${ }^{27}$ The tenure of office of the President corresponded with that of Parliament, that is five years unless the President sooner dissolved Parliament. The President could be removed from office on the grounds of mental or physical incapacity, for violation of the Constitution or gross misconduct. ${ }^{28}$

The Constitution vested broad executive power in the President. ${ }^{29}$ While ministries were created by Parliament, appointment of ministers from among members of the National Assembly was vested in the President, and ministers were to serve at the President's pleasure. The ministers constituted the Cabinet. ${ }^{30}$ Its role was to advise

\footnotetext{
${ }^{23}$ Provisions concerning the alteration of the Constitution were contained in section 72 . It provided in section 72(1), (2)(a)(b) that a bill amending the Constitution shall not be passed unless "the bill is supported on second and third reading by the votes of not less than two-thirds of all the members of the Assembly". In so far as the amendment concerned Chapter III and Chapter VII of the Constitution, section $72(3)(a)(b)(c)$ required the amendment to be approved by a national referendum.

${ }^{24}$ R. Hall, Zambia, London, 1964.

${ }^{25}$ Art. 33(1) (2)(a)(b)(c).

26 Art. 33(4)(b).

27 Art. 33(4)(e).

${ }^{28}$ Art. 36(l)(a)(b) (2) (3)(a)(b)(c) (4) (5).

${ }^{29}$ Art. 48(1) (2) (3).

${ }^{30}$ Art. 44(1) (2) (3)(a)(b)(c).
} 
the President on government policy and such matters as were referred to it by the President. Throughout the first 26 years of independence the presidency grew in stature at the expense of the other organs of the state-the National Assembly and the judiciary. The Cabinet in particular increasingly appeared unable to influence the decisions of the President. Further, the President developed a practice of appointing Special Assistants on various subjects of governance, even labelling some "ministers". These individuals appeared more important and closer to the President than the Cabinet members. ${ }^{31}$

It is no exaggeration to describe the powers of the President under the 1964 Constitution as enormous. A detailed recitation is beyond the present scope. However, in addition to those powers already discussed, the Constitution empowered the President to appoint the Vice-President from among the members of the National Assembly, including from among the five members of that body which the Constitution empowered the President to name. ${ }^{32}$ Thus the President controlled succession to the presidency in the event of death, disability or removal. He acquired great power as commander-in-chief of the armed forces. ${ }^{33}$ His veto power over legislation was considerable. Even if a measure was re-passed by a two-thirds majority of Parliament, the President could prevent its becoming law by dissolving Parliament. The President's powers of detention had great impact on the protection of fundamental rights. His de facto powers were enhanced greatly by his personal popularity and his control over the apparatus of UNIP, which held decisive majorities in Parliament. ${ }^{34}$

\section{Parliament}

The 1964 Constitution vested all legislative powers in Parliament, ${ }^{35}$ which consisted of the President and the National Assembly, the latter having 75 elected members plus up to five members nominated by the President. ${ }^{36}$ To be elected to Parliament a person had to be a Zambian citizen and have attained the age of 21. Parliament was presided over by a Speaker elected by the National Assembly from its membership or from those qualified to be elected to that body. ${ }^{37}$ The legislative power of Parliament was exercised through bills passed by the National Assembly and assented to by the President. ${ }^{38}$ In most circumstances the President could withhold assent to a bill, thereby in effect vetoing it. When, as noted, the President withheld assent to a bill, under most circumstances the bill could be returned to the National Assembly and re-enacted, provided that it had the support of two-thirds of the members of Parliament. If such bill was again presented to the President, the Constitution required the President to sign it or dissolve Parliament. ${ }^{39}$

31 Mwanakatwe, above, 107. B.C. Chikulo also made this observation in "Decentralization in centralism: an analysis of the Zambian experience (1964-1981)", in K. Osei-Hwedie and M. Ndulo (eds.), Issues in Zambian Development, Lusaka, 1985, 340.

${ }^{32}$ Art. 41(1).

33 Art. 49(1).

34 The President was also the President of the ruling party, UNIP.

35 Art. 57.

36 Art. 58.

37 Art. 63(1).

38 Art. $71(1)$.

39 Art. $71(5)$ (6). 
Seven or more Members of Parliament could challenge a bill on the grounds that it violated provisions of the Constitution which protected the fundamental rights of an individual by asking the Speaker to refer the matter to a tribunal. Thereupon the Chief Justice was empowered to appoint a tribunal to report whether, in the opinion of the tribunal, any or all provisions of the bill were inconsistent with the Constitution. ${ }^{40}$ This procedure was never used throughout the life of the 1964 Constitution.

The Constitution provided for a House of Chiefs, mainly a deliberative body. ${ }^{41} \mathrm{It}$ could consider and discuss any bill introduced or proposed to be introduced in the National Assembly or any other matter referred to the House by the President. It had no legislative powers and, as such, could not enact or block legislation. Parliament retained its essentially British characteristics until the introduction of the one-party state in 1973. There was throughout a vibrant opposition present in Parliament. The presence of such opposition consolidated democracy in Zambia and enhanced the prestige and reputation of the Zambian Parliament. The African National Congress played an important role in making parliamentary business effective under the multiparty system. Its members kept ministers alert and accountable to the public for ministerial actions. ${ }^{42}$

\section{The judiciary}

The judiciary consisted of the Court of Appeal and the High Court. Both were established as courts of superior record. The Court of Appeal was the highest court in the land, with sweeping appellate jurisdiction. ${ }^{43}$ The High Court had unlimited original jurisdiction to hear and determine any civil or criminal proceedings under any law. ${ }^{44}$ The High Court also had jurisdiction to supervise any civil or criminal proceedings before a subordinate court or any court-martial. It could make orders, issue writs or give directions as it might consider appropriate for the purpose of ensuring that justice was duly administered by any court. ${ }^{45}$ The Chief Justice was appointed by the President. ${ }^{46}$ The judges of the Court of Appeal and of the High Court were appointed by the President, acting in accordance with the advice of the Judicial Service Commission. ${ }^{47}$ The judges had security of tenure and could be removed only for infirmity of body or mind or for misbehaviour, and even then they could be removed only in accordance with the constitutionally prescribed procedure. ${ }^{48}$

On the whole these judges remained reasonably independent, though there were some incidents of executive interference. In 1969 the President questioned a decision of a High Court judge reducing the sentence of two Portuguese soldiers who had been convicted by a subordinate court of illegal entry into Zambia. This led to the resignation of the Chief Justice who led other judges in support of the judge so criticized. ${ }^{49}$ Perhaps more serious than this isolated incident was the President's

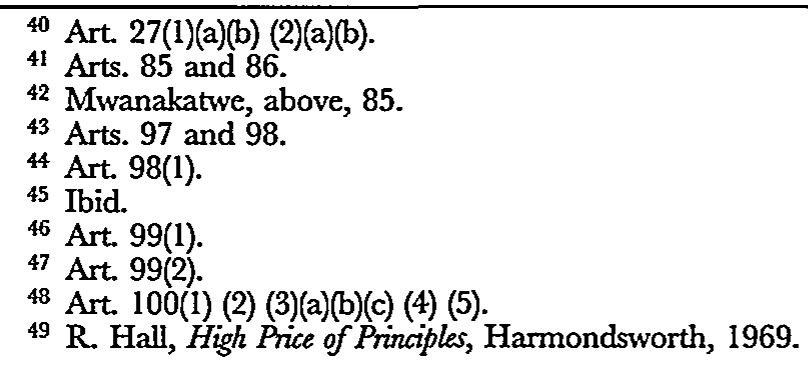


practice of appointing sitting judges to other, non-judicial, government positions. This meant resignation from the bench. Generally perceived as aimed at judges who had rendered decisions unsatisfactory to the President or whom the President feared would render such decisions, this practice undermined the independence of the judiciary.

The subordinate courts (magistrates courts) and local courts were the creatures of statute. The former closely resembled their colonial predecessors. The Local Gourt Ordinance supplanted the colonial Native Courts Ordinance. The local courts primarily administered customary law. ${ }^{50}$

\section{The Bill of Rights}

The 1964 Constitution contained an extensive Bill of Rights. ${ }^{51}$ Under it every person in Zambia, regardless of race, place of origin, political opinions, colour, creed or sex, was entitled to fundamental rights and freedoms of the individual. The rights enumerated in the Constitution were: life, liberty, security of the person and the protection of law, freedom of conscience, expression and assembly and association, freedom for the privacy of the home and other property, and freedom from deprivation of property without compensation. ${ }^{52}$ The rights, however, were by no means absolute. They were subject to detailed limitations, popularly referred to as "savings provisions", contained in the very sections granting the individual rights. Designed to ensure that the enjoyment of the rights and freedoms by any individual did not prejudice the rights and freedoms of others or the public interest, in practice these limitations were used by government to tamper with individual rights. A significant limitation applied to provisions outlawing discrimination on grounds of race, sex and place of origin. Whereas the Constitution outlawed any provisions of a law that was discriminatory, either on its face or in its effect, it also provided that the protection would not govern applications of customary law to members of a particular race or tribe..$^{53}$ This in effect exempted from the Bill of Rights the root cause of much of the discrimination suffered by women in Zambian society.

Subject to these substantial limitations, the fundamental rights were judicially enforceable. Any person who alleged that any of his or her rights as protected by the Constitution were being infringed could apply to the High Court for redress ${ }^{54}$ and that court could issue orders or writs and give directions appropriate for the purpose of enforcing any of the provisions protecting fundamental rights. ${ }^{55}$ Many applications found their way into the courts, and the courts were generally responsive to the complaints of individuals concerning the violation of their rights. ${ }^{56}$ Quite clearly, however, they trod very carefully in cases with political overtones. This was unfortunate, for it is in precisely such cases that the rights of individuals are most

\footnotetext{
${ }^{50}$ For a detailed study of the lower courts see F.O. Spalding et al., "One nation, one judiciary: the lower courts of Zambia", (1970) 1 Zambia Law Joumal 1.

51 Chapter III of the Constitution of 1964.

52 Arts. 13-25.

53 Art. 25(4)(c)(d)(e).

54 Art. 28(1).

55 Art. 28(2)(a)(b).

${ }^{56}$ E.g. Kachasu v. Attomey-General (1964) ZR 145; Attomey-General v. Mumba (1974) ZR 218; Chimba \& Others v. Attomgy-General (1972) ZR 165 and Patel v. Attomey-General (1968) ZR 99.
} 
likely to be violated. The limitations took a particularly heavy toll in cases involving detention without trial, that is detentions on the basis of an executively declared state of emergency. Nevertheless, this period did establish the principle of judicial review with a potential for later, more effective protection of fundamental rights.

\section{The process of amendment}

The 1964 Constitution contained stricter procedures to be followed for the alteration of the Constitution than for the enactment of ordinary legislation. A bill to amend the Constitution required the votes of not less than two-thirds of all of the members of the National Assembly. ${ }^{57}$ Further, insofar as it altered any part of the Constitution relating to fundamental rights, such a bill could not come into force until submitted to a national referendum and approved thereby. ${ }^{58}$ Intended to make it difficult to alter provisions of the Constitution protecting rights of individuals, this provision was unfortunately targeted for repeal early in the life of the Constitution. It was eliminated by a 1969 amendment and referendum billed as the "referendum to end all referenda". ${ }^{59}$ This repeal was aimed specifically at facilitating amendments to the rights to property, but its implications were far broader. In 1968 the government had embarked on economic reforms designed to enhance African participation in the economy. ${ }^{60}$ The government desired to take over substantial sectors of private businesses through large-scale nationalizations. The property clause as it existed was seen as an impediment to these measures. The removal of the referendum clause was later to facilitate the adoption of a one-party system of government. It avoided the need for a referendum to do so and left the entire Constitution subject to amendment if those in control possessed a majority of two-thirds in Parliament.

\section{The 1973 Constitution-The Segond Republic, The One-Party STATE}

In 1972 the government announced that it had decided to turn Zambia into a one-party state. ${ }^{61}$ This was stated to be in the interest of unity and economic development, but the context of the decision strongly suggests that it was in reality a response to mounting divisions within the ruling party perceived as threatening its hold on power. ${ }^{62}$ At independence there was remarkable unity among the people of Zambia. After independence sectionalism appeared. In 1971 UNIP experienced its most serious internal strife. In August of that year a splinter group formed its own political party which appeared to be tribally motivated. Called the United Progressive Party (UPP), the group was led by the then Vice-President of the country, Simon

\footnotetext{
57 Art. 72(1).

58 Art. 72(3)(a)(b)(c).

59 Constitutional (Amendment) (No. 3) Act of 1969 amended the Constitution so that, after it became law, it would no longer be necessary to submit to a referendum any Act of Parliament which provided for the alteration of Chapters III and VII and arts. 71(2), 72 and 73 of the Constitution.

${ }_{60}$ See B. Turok, Development in Zambia: A Reader, London, 1979, 71.

6! Mwanakatwe, above, 88.

62 Mubako, above, 67-68. Mubako supports the view that the decision to introduce the "One Party Democracy" at the time and in the manner it was introduced was largely influenced by political developments in the ruling party UNIP.
} 
Kapwepwe. The response from UNIP members was a demand for a one-party state. In the by-elections held in 1971 the leader of UPP won a parliamentary seat, suggesting the potential capability of the newly formed party to pose a serious challenge to UNIP in a general election. ${ }^{63}$ Shortly afterwards it was announced that Zambia was to become a one-party state. The concept was not new in Africa; indeed neighbouring Tanzania had already so proceeded. In 1973 a Constitutional Commission was appointed to recommend the form and details of the single party system. Its work is worth summarizing. Chaired by Vice-President Mainza Chona, the Commission travelled widely throughout Zambia, holding hearings and taking evidence on the framework and features people desired in the operation of the new type of government. The Commission received a large volume of written and oral submissions, deliberated the same, and presented its report in October $1972 .{ }^{64}$ The thoroughness, balance and thoughtfulness of this report have been praised widely and some of its proposals had an impact on what came later.

The recommended preamble incorporated the philosophy of Humanism, an ideological commitment long expounded by Kaunda. Differing from communism in its respect for the integrity and dignity of the individual, the approach carried with it heavy overtones of socialism. The Chona Commission made sweeping recommendations in the area of human rights. It recommended considerable curtailment of the President's powers of detention. Concerned about the effects of longterm concentrations of power, the Commission recommended that a President be permitted to serve no more than two consecutive five-year terms. A division of executive powers was proposed between the President and a Prime Minister who would have the authority to appoint the other ministers. With respect to elections, the Commission advanced a proposal whereby the Party would place three presidential candidates before the electorate. The Commission recommended a Leadership Code, a device to impose conditions of financial probity on national leaders both as an example to the nation and a control upon use of official power for the attainment of private wealth.

The government's response was mixed. ${ }^{65}$ Of course the basic concept of the one-party state was accepted. Significantly, however, the government rejected the recommendation for limitation of a President to two consecutive terms. The proposal that the party present three candidates to the electorate was likewise set aside in favour of the naming of a single candidate for the people to accept or reject. While the position of Prime Minister was accepted, the powers of that office were substantially reduced in favour of the preservation of the powers of the President. The powers of detention, used against the leaders of UPP in 1972, were to remain substantially intact.

The Second Republic came into being on 25 August, 1973, the one-party Constitution being enacted by the National Assembly and assented to by the President. ${ }^{66}$ There was no debate over the Constitution outside what had taken place before the Chona Commission. The Zambian Independence Act, 1964, and the

63 Mwanakatwe, above, 86.

64 Report of the National Commission on the Establishment of a One-Party Participatory Democracy in Zambia, Government Printer, Lusaka, 1971.

65 Government White Paper No. 1 of 1972.

66 The Constitution of Zambia Act, 1973. 
Zambia Independence Order, 1964, were repealed. In that sense the Constitution was truly a Zambian document as opposed to its predecessor which was legislated into being by the British Parliament as part of the Act that severed Zambia's connection to the British Crown and granted it independence. The preamble declared Zambia a "One-Party Participatory Democracy under the Philosophy of Humanism". It declared the right of all men freely to determine and build their own political, economic and social system by ways and means of their own free choice. It recognized "the protection of life, liberty and property, freedom of conscience, expression and association within the context of our National Constitution"67 (emphasis added). The provisions of the Constitution relating to the executive, the judiciary and Parliament remained substantially the same as those contained in the 1964 Constitution. ${ }^{68}$ The executive arrangement changed in that the Secretary-General of the Party, in line with the new political order, became the deputy leader of the nation and acted in the absence of the President. ${ }^{69}$ The Constitution also created the office of the Prime Minister to be leader of government business in Parliament. ${ }^{70}$

By far the most significant feature of the 1973 Constitution was the declaration of Zambia as a one-party state. Enacted at a low point in the country's economic fortunes with attendant unhappiness of the populace and against the background of recent political turmoil within the ruling party, this Constitution was set forth as a better model for the management of political conflict in a country in dire need of stability and rapid economic development. The Constitution declared the United National Independence Party as the one and only political party allowed to exist and to operate in the country. ${ }^{71}$ It became illegal to form or attempt to form any other political party or organization, and illegal to belong to any political party other than UNIP. This far-reaching change completely altered the democratic character of Zambia. Like the 1964 Constitution, it contained a Bill of Rights, guaranteeing those fundamental personal interests set forth in the preamble. These rights, however, were rendered practically meaningless in the context of a one-party state with sweeping executive powers. Freedom of speech and assembly could be exercised only within the United National Independence Party. The presidential power of detention without trial was continued in certain situations. ${ }^{72}$ The Constitution provided for the application of the Emergency Powers Act and the Public Security Regulations when a state of emergency was declared to exist. For most of its existence Zambia had been under such a state of emergency, first as a result of a pre-independence religious rebellion and later because of the liberation wars in southern Africa. The police were given extensive powers in the case of emergency. A high ranking police officer was empowered to arrest and detain any person in respect of whom he or she had reason to believe that there were grounds justifying such detention. No warrant was required. The law required the state within 14 days of detention to give reasons in detail therefor, ${ }^{73}$ and also provided for a review by a tribunal at the request of the detainee,

67 Ibid.

68 Arts. 107-116-Judiciary; 63-94-Parliament; 37-62-Executive.

69 The Constitution of Zambia Act, 1973, art. 42(1) (2).

70 Ibid., art. 48.

71 Ibid., art. 4(1) (2).

72 Ibid., art. 26.

73 Ibid., art. 27(1)(a). 
but not sooner than one year after detention. ${ }^{74}$ The tribunal, appointed by the Chief Justice, submitted recommendations to the President, but these were not binding upon him. ${ }^{75}$

Through the life of the Second Republic the power to detain was misused to reach political opponents. Cases found their way to the courts on writs of habeas corpus, but the courts, especially in political cases, routinely upheld the state's power to detain individuals without trial. Courts refused to examine the facts on which government had determined that an individual was a threat to national security. In some cases without political overtones the courts used their independence to protect citizens through ordering their release.

One notable improvement in the 1973 Constitution over its predecessor was the introduction of the Office of the Investigator General. ${ }^{76}$ Analogous to that of an ombudsman, the Investigator General had jurisdiction to inquire into the conduct of any person in the public service with respect to the exercise of authority or abuse thereof. This useful tool had its limits. The Investigator General had no power to discipline public servants or to effectuate change. The powers were to submit findings and recommendations to the President, who was not required to implement them or even to disclose the findings and recommendations received. On the whole the President followed the recommendations, which significantly were not political in character.

The introduction of the one-party system of government greatly strengthened the executive President. In Zambia since independence UNIP leaders had always proclaimed their wish to strike a balance between popular participation and central control in the development process. The desired goal was found difficult to achieve in a multi-party system. The one-party system was perceived as a way to achieve that balance regarded as prerequisite for development. Subsequent experience in Zambia showed otherwise. There never was any decentralization of power. An example was the concentration of power in the manner in which elections to Parliament were organized and conducted. There were two stages for election of members of the National Assembly. The first consisted of primaries in each of the constituencies in which voting was by an electoral college of party officials, officials elected by party members only. This primary provided an opportunity for party officials to eliminate candidates they did not like. The next stage was the vetting of candidates by the Gentral Committee of UNIP. Its power was to eliminate a candidate considered "inimical to the interests of the State". This test was never defined and remained a subjective test in the mind of the executive branch. In practice the system was used to eliminate potential political rivals. ${ }^{77}$ With respect to elections of a President, the Party adopted one candidate, and voters were enabled only to vote yes or no. ${ }^{78}$

\footnotetext{
74 Ibid., art. 27(1)(c).

75 Ibid., art. 27(2).

76 Ibid., art. 117.

77 B.C. Chikulo, "Elections in a one-party participatory democracy", in Turok, above, 201; see also C. Gertzel et al., The Dynamics of the One-Party State in Zambia, Manchester, 1984, 29.

78 This was based on the philosophy that the party was supreme. The supremacy of the party was recognized in the Constitution of Zambia (Amendment) Act No. 22 of 1975. For a discussion of this amendment see L.S. Zimba, "The Constitution of Zambia (Amendment) Act No. 22 of 1975:
} 
The 1973 Constitution laid the groundwork for a Leadership Code. Recommended by the Chona Commission and championed by President Kaunda, the Code had as its purpose the imposition of strict financial standards upon all in leadership posts from the President to the civil service, including employees of parastal bodies. Provision for such a Code was contained in the 1973 Constitution, ${ }^{79}$ but implementing regulations did not appear until 1976. ${ }^{80}$ The much debated proposal included restrictions on ownership of land, prohibition on the receipt of gifts and the publication of personal assets. It was designed to prevent the transformation of political power into personal wealth, but was not successful. Once implemented, its enforcement was spotty; presidential exemptions were granted, and evasions were frequent. ${ }^{81}$ The expressed hostility of government to capitalism and the ambivalence of its actions in this regard created a situation in which many political leaders failed to invest effectively for the futures of themselves and their families. The result was the development of untoward zeal on the part of political leaders to retain power at all costs. The rewards, monetary and otherwise, of holding office were substantial; their loss in many instances became devastating. The bad fruits of this lie in the manipulation of the Constitution for the purpose of retaining power.

\section{The 1991 Constitution: The Third Republic}

The years of the Second Republic and the one-party state were difficult for Zambia. Throughout the period from 1973 to 1991 the economy of the country continued to stagnate with attendant unhappiness of many segments of society. ${ }^{82}$ "The Party and Its Government" became increasingly unpopular. The trade union movement (never captured by the Party), the business community, the churches, scholars and students at the University, the legal profession: all from time to time expressed increasing hostility. These were groups difficult for the government to control. Attempts at coups, while unsuccessful, contributed to the unsettled quality of the political atmosphere. ${ }^{83}$

As the decade of the 1980s drew to a close, demands for an end to the one-party state became more insistent. Pro-democracy groups, initially spurred by the trade union movement, formed the Movement for Multi-party Democracy (MMD). ${ }^{84}$ The "winds of change" in Eastern Europe came to Africa in general and to Zambia in

the legal recognition of the principle of 'party supremacy' in Zambia", (1982) 14 Zambia Law Joumal, 82.

79 The Constitution of Zambia Act, 1973, Art. 32.

80 The Leadership Code Act, 1976.

81 The 1991 Constitutional Commission recommended the abolition of the Leadership Code on the grounds that "although well intended, it had failed to achieve its objectives": Report of the Constitution Commission, 1991, 187.

82 There are several accounts of the economic situation during this period. See, for example, Mwanakatwe, above, 113; "Sub-Saharan Africa: from crisis to sustainable growth", World Bank Report, 1989; "African economies: African alternative framework for structural adjustment programmes for social economic recovery and transformation (AAF-SAF)", United Nations Economic Commission for Africa (E/ECA/CM.15/6/Rev.3).

83 There were two significant coup attempts, in 1980 and 1990. The 1990 attempt followed food riots to protest against the rising cost of food, particularly maize meal. See Mwanakatwe, above, 165.

${ }_{84}$ The MMD was formed at a meeting held at the Garden Motel in Lusaka in July 1990. It was largely an initiative of intellectuals, students and unions. 
particular. At first resistant, the government then announced a referendum on whether to continue the one-party state. Subsequently, in September 1990, it changed its mind and abandoned the referendum. Rather it promptly amended the Constitution to permit formation of other parties and announced an undertaking to introduce comprehensive amendments to the Constitution. It also promised to hold elections by the end of 1991, two years before the scheduled end of the government's five-year term. ${ }^{85}$

The government appointed a Constitutional Commission chaired by M.P. Mvunga, then Solicitor-General. Known as the Mvunga Commission, this body toured the country extensively and obtained the views of a broad range of people on a future constitution for Zambia. ${ }^{86} \mathrm{MMO}$ opposed the creation of this commission; it advocated the re-introduction of the 1964 British enacted Independence Constitution, with necessary amendments to reflect the changed circumstances. The Commission produced recommendations, some of which were rejected by both the government and the opposition parties. ${ }^{87}$ The government picked the recommendations it preferred, rejected the others, and prepared a constitution for adoption by Parliament. Though it provided for multi-party elections, the document was rejected by MMD, not only for its contents but because the Commission was perceived as dominated by UNIP and its product was, to the extent approved by UNIP, to be enacted by a Parliament overwhelmingly controlled by that party ${ }^{88} \mathrm{~A}$ serious stalemate ensued, softened though not ended by a conference organized by students at the University. ${ }^{89}$ The solution came when the churches organized a national conference and mediated the dispute. This led to agreement to reformulate the 1973 Constitution in order to facilitate the re-introduction of multi-party politics. ${ }^{90}$

The 1991 Constitution was agreed upon by all political parties, enacted by Parliament on 2 August and approved by the President on 29 August. The provision establishing UNIP as the sole political party was removed, article 21 providing for the "right to assemble freely and associate with other persons and in particular to form or belong to any political party ...". There was no reference in the preamble to the "Philosophy of Humanism" or the gloss of socialism which it had acquired. Significantly, article 1 declared, "this Constitution is the Supreme Law of Zambia and if any other law is inconsistent with this Constitution, that other law shall, to the extent of the inconsistency, be void". 91 This emphasized the end to notions of party supremacy. It also carried significant implications regarding the power of judicial review of the constitutionality of legislation.

The 1991 Constitution, like its predecessor, provided for the protection of fundamental rights and freedoms of the individual, but retained the limitations contained

85 In 1990 a Referendum Commission was established. A provision in the Referendum Act allowed the Commission to issue instructions "to any public authority, public individual, public office". The Commission interpreted this provision freely and liberally and was able to use it to override government power over the media and police in its efforts to ensure a level playing field.

${ }_{86}$ The Commission was appointed on 8 October, 1990, by Statutory Instrument No. 135, 1990.

87 Report of the Constitution Commission, April 1991.

${ }_{88}$ Mwanakatwe, above, 215.

89 Ibid., 218.

90 Ibid., 219.

91 The Constitution of Zambia Act, 1991, art. 1(2). 
in the 1973 Constitution. ${ }^{92}$ For example, the provisions outlawing discrimination continued to be subject to the application of customary law, thus continuing the disadvantaging of women. ${ }^{93}$ Freedom of movement remained. subject to detention laws, ${ }^{94}$ the only improvement being that a declaration of a state of emergency was made subject to parliamentary approval.

Most importantly, provisions relating to the election of a President changed. Under the 1991 Constitution a President was to be elected by direct universal adult suffrage, and elections for the presidency were to be held whenever the National Assembly was dissolved..$^{95}$ The normal life of a National Assembly remained at five years. To be President, a person had to be a Zambian citizen, to have attained the age of 35 years and to belong to a political party. ${ }^{96}$ The President was required to obtain 50 per cent or more of the votes in order to be elected. If at the initial poll no candidate received more than 50 per cent of the valid votes cast, the candidates having the highest and next highest number of votes were to be submitted to the National Assembly which would elect a President on a simple majority. The Constitution provided that every President shall hold office for five years. ${ }^{97}$ It also limited a President to two terms, providing for computation of such terms only from the date of the Constitution. ${ }^{98}$

This Constitution also introduced the requirement of parliamentary ratification of appointments of judges, the Attorney-General and the Solicitor General. ${ }^{99}$ The requirement that cabinet ministers be drawn from Parliament was retained, as was the power of the President to nominate up to eight members of the National Assembly, excluding unsuccessful candidates in the last preceding election. ${ }^{100}$ The 1991 Constitution provided for its amendment by a two-thirds vote of the members of the Assembly. ${ }^{101}$ The requirement of the Independence Constitution that amendments to Part III, Protection of Fundamental Rights and Freedoms of the Individual, could not be effected without approval in a national referendum, was re-introduced. ${ }^{102}$

Barely two months after the enactment of the 1991 Constitution elections were held on 31 October. The results represented an overwhelming victory for MMD. Frederick Chiluba was elected President by a wide margin over Kenneth Kaunda, who had served uninterruptedly as President since 1964, the entire life of the Republic. MMD captured 125 of 150 seats in the National Assembly. With only 25 members, UNIP lacked the numbers to create an effective opposition in Parliament. The leadership of the new government was broadly based; all sections of the country were represented. Kaunda relinquished power graciously.

92 Part III of the Constitution. For the limitations on the rights see arts. 16(2); 17(2)(a)(b); 19(5); 20(3)(a)(b); 21(2)(a)(b); and 25.

93 The Constitution' of Zambia Act, 1991, art. 23(4)(d)(e).

94 Ibid., arts. 22(3)(a)(b) and 26(1).

95 Ibid., art. 34(1) (2).

96 Ibid., art. $34(3)(\mathrm{a})(\mathrm{b})(\mathrm{c})(\mathrm{d})$.

97 Ibid., art. 34(6) (7) (8) (11).

98 Ibid., art. 35(2).

99 Ibid., arts. 93(1) (2); 95(1); 54(1); 55(1) and 56(1).

100 Ibid., art. 68.

101 Ibid., art. 79(1)(a)(b).

102 Ibid., art. 79(3). 
This Zambian exercise in democracy met with unstinting praise from the international community. ${ }^{103}$ After decades of turbulence in much of the continent, this episode was greeted hopefully as a harbinger of better days in other places. One concern lingered: the size of the turnout on 31 October was disappointing. Reasons advanced for this included a hasty determination of constituencies, inefficient management of the registration process, distances of polling stations from many people, and fears (which turned out to be unfounded) that violence would attend the voting process. ${ }^{104}$ This negative factor was overshadowed by the twin accomplishments of 1991: the return of multi-party democracy and the orderly transfer of political power.

There is much to be said for the Constitution of 1991. Although enacted by Parliament, it was, as Constitutions in their nature must be, the product of compromise. It maintained, indeed strengthened, the separation of legislative, executive and judicial powers. It reduced the domination of the executive. It strengthened the power of a largely independent judiciary by its direct assertion of the supremacy of the Constitution.

\section{THE 1996 Constitution}

A thoughtful observer perceived the 1991 Constitution as one "that can serve the interests of the people for a long time". ${ }^{105}$ As a part of the compromise on which that Constitution was based, however, representatives of political parties, especially MMD, undertook to promote constitutional debates once multi-party politics became firmly re-established in the country. Specifically, MMD campaigned in the 1991 elections on the platform that if elected to power it would change the 1991 Constitution and replace it with one which would be above partisan considerations and would strengthen democracy and the protection of human rights. A year after the government acquired power, the Minister of Legal Affairs created a task force to review the Constitution. Comprising seven members, it was chaired by the Attorney-General. Subsequently, the government was persuaded that it was unwise to leave a task of this magnitude in the hands of a few under the chairmanship of the principal legal advisor to the government. For the third time, and for the second within three years, the government appointed a Constitutional Review Commission. Popularly known as the Mwanakatwe Commission (after its chairman), this body received terms of reference far wider than those accorded any previous Constitutional Commission. ${ }^{106}$ It was directed to recommend a system that will "ensure that Zambia is governed in a manner that will promote the democratic principles of regular and fair elections, transparency and accountability, and that will guard against the re-emergence of a dictatorial form of government; ... appropriate arrangements for the entrenchment and protection of human rights, the rule of law and good governance; ... the

\footnotetext{
${ }^{103}$ Commonwealth Human Rights Initiative Report, The Post, 24 September, 1996; Michael Bratton, "Zambia starts over", (1992) 3 Joumal of Democracy, 81; John Milimo, "Multiparty democracy in Africa: lessons from Zambia", (1993) 10 International Joumal of World Peace, 35; and National Democratic Institute for International Affairs, Uneven Paths: Advancing Democragy in Southem Africa, Windhoek, 1993, 37.

104 Mwanakatwe, above, 229.

105 Ibid., 223.

106 The Commission was appointed on 22 November, 1993, under Statutory Instrument No. 151 of 1993 as amended by Statutory Instrument No. 173 of 1993.
} 
competence, impartiality and independence of the judiciary, ..." ${ }^{107}$ It was directed to recommend "whether the Constitution should be adopted by the National Assembly or by a Constituent Assembly, by a National Referendum or by any other method; ... [and] a suitable method of amending any part of the Constitution ...". ${ }^{108}$ This Commission toured the country and collected a large volume of views of the populace. Many of its recommendations, had they been adopted, would have greatly strengthened democracy in Zambia. It recommended that to achieve maximum consensus the Constitution should be adopted through a Constituent Assembly attended by representatives of all political parties and by those drawn from many segments of Zambian society: the professions, the labour movement, employers, churches, women's groups, the universities and their students, and others on a very detailed list. ${ }^{109}$ It recommended that a referendum be required for subsequent amendments. ${ }^{110}$ It decried the long-standing practice by which Zambian Constitutions have appeared as schedules to Acts of Parliament, noting that this is a heritage of the colonial era when even the Independence Constitution was a schedule to a British Order-in-Council. The Commission observed that many were anxious that future constitutional amendments not be enacted like ordinary pieces of legislation. "A Constitution meant to stand the test of time should not be subject to wilful amendments."

In terms of substance a number of recommendations are noteworthy. The Commission's rejection of requests that the preamble recite that Zambia is a Christian nation was significant. ${ }^{112}$ Following the preamble the Commission's draft included a chapter on "Directive Principles of State Policy", an aspirational list of principles for the guidance of all branches of government in lawmaking, administration and adjudication, all in the interest of establishment of a just and democratic society. The principles covered a wide range of policy areas. They were, however, expressly made non-enforceable in court proceedings. ${ }^{113}$ In the field of fundamental rights the draft recommended strengthening some rights and adding others. Those added referred to residence, human dignity and reputation, culture, marriage, a clean environment and equal pay for equal work. ${ }^{114}$ Freedom of the press and related rights of journalists were strengthened. ${ }^{115}$ Academic and intellectual freedom and the right to strike and lock out were scheduled for protection. ${ }^{116}$ Most notable was a drastic increase in the protection of rights of women and the prohibition of laws, customary practices and stereotypes which worked against the dignity of women. ${ }^{117}$ Economic protections of women, including maternity leave, were included, as was a

\footnotetext{
107 Terms of Reference of the Commission (1), (2), (3), (4). The terms of reference are contained in Statutory Instrument No. 151 of 1993.

108 Ibid., term of reference (9).

109 Report of the Constitutional Review Commission, 1995, Chapter 27 of the Report, recommendation 27 and $27(1)$.

110 Ibid., Chapter 28 of the Report.

111 Ibid., 64.

112 Ibid., Chapter 3, paragraph 3.6, 10.

113 Ibid., Chapter 4, paragraphs 4.0-4.3.7.

114 Ibid., Chapter 7, paragraph 7.2, 15.

115 Ibid., Chapter 7, paragraph 7.2.15 and paragraph 7.2.16, 18.

116 Ibid., Chapter 7, paragraphs 7.2.17 and 7.2.20,18 and 19.

117 Ibid., Chapter 7, paragraph 7.2.21, 19.
} 
comprehensive article on children's rights. ${ }^{118}$ In terms of the enforcement of fundamental rights, the draft extended the range of entities that could bring actions to enforce in a court of law any of the enumerated rights. ${ }^{119}$ It partially removed the qualifications that derogated from the rights in previous constitutions.

While progressive on many fronts, the Mwanakatwe Commission inexplicably recommended discriminatory restrictions on who could stand for the office of President. A person to be qualified as a candidate for election as President had to be a citizen of Zambia, born in Zambia, of parents who are Zambian citizens and also born in Zambia. ${ }^{120}$ The draft also provided that "no person who has twice been elected as President shall be eligible for re-election to that office". ${ }^{121}$ The corresponding provision in the 1991 Constitution specifically provided that it should apply only to a person twice elected President after the date of the Constitution of $1991 .^{122}$ Elimination of this proviso by the Mwanakatwe Commission, together with the hitherto non-existent requirement that a presidential candidate's parents must be born in Zambia, represent a transparent attempt to bar former President Kaunda from again becoming a candidate for President. His parents were born in what is now Malawi, and he had served as President for more than two five-year terms. Given the composition of the Commission, these recommendations are surprising and can only reflect pressure from those desiring the retention in power of MMD.

The Commission also included a novel recommendation that upon becoming a candidate in any election or accepting appointment to any office in any political party, a chief shall give up the chieftainship. ${ }^{123}$ The appointment of Cabinet Ministers from persons outside Parliament was recommended, and that appointment to the Cabinet of a member of the National Assembly would operate to vacate the seat in Parliament. ${ }^{124}$ The only other significant change recommended with respect to the National Assembly was the right of a constituency to recall a representative on the petition of a prescribed number of registered voters. ${ }^{125}$

With respect to the judiciary, the draft advocated the creation of a Constitutional Court to exercise jurisdiction over any alleged violation or threatened violation of any right guaranteed by the Constitution and any matter relating to the interpretation of that document. ${ }^{126}$ For the first time the draft recommended provisions on the

118 Ibid., Chapter 7, paragraph 7.2.23, 19.

119 Ibid., Chapter 7, paragraph 7.6, 21.

120 Ibid., Chapter 11, paragraph 11.4.1.

121 Ibid., Chapter 11, paragraph 11.5, 29. This has been implemented in the Constitution of Zambia (Amendment) Act No. 18 of 1996, art. 35(2).

122 Art. 35(2) of the Constitution of Zambia Act, 1991, read "... after the commencement of this Constitution no person who holds or has held office as President for two terms of five years each, shall be eligible for re-election to that office".

${ }_{123}$ The Constitution of Zambia Act (Amendment) Act No. 18, 1996, provides that "a Chief shall not be qualified for election as a member of the National Assembly" and art. 65(4) provides that "a Chief who intends to stand for election to the National Assembly shall abdicate his Chieftaincy before lodging his nomination". The Commission version would have only required the Chief to resign upon being elected to Parliament. See Report of the Constitutional Review Commission, 1995, Chapter 12, paragraph 12.6, 36 .

124 Report of the Constitutional Revizw Commission, 1995, Chapter 11, paragraph 11.9, 32.

125 Ibid., Chapter 12, paragraph 12.25, 40.

126 Ibid., Chapter 13, paragraph 13.6.1, 42. 
Bank of Zambia, ${ }^{127}$ local government, ${ }^{128}$ the army and police, ${ }^{129}$ thus further involving the Constitution in the details of governmental structure. The Report further recommended the creation of a human rights commission to investigate on its own initiative $^{130}$ or on a complaint made by one or more persons, any human rights violations, and to promote programmes aimed at enhancing respect for human rights. It further sought to restrict declarations of emergencies to situations involving threats to the security of the country by invasion, general insurrection, or at a time of national disaster. It also provided a check in that the declaration of an emergency was made subject to judicial review by the Constitutional Court. ${ }^{131}$

The government, in a white paper, rejected most of the progressive recommendations of the Mwanakatwe Report. ${ }^{132}$ It rejected the introduction of several new personal rights, the introduction of a Constitutional Court, the recommendations on rights of women and a recommendation for the establishment of an independent Electorial Commission to conduct elections in Zambia. ${ }^{133}$ It clearly departed from its original promise in 1991 to introduce in Zambia a Constitution that strengthened individual rights and freedoms and lessened the power of the executive. It rejected the Mwanakatwe Report's recommendation that there should be separation of Church and State, instead deciding that the preamble would contain a provision declaring Zambia a Christian state. ${ }^{134}$ Significantly, the government did accept the recommendation that a presidential candidate must be born of parents both of whom are Zambians by birth or descent, ${ }^{135}$ and the retroactive application of the two-term amendment. ${ }^{136}$ The government also accepted the banning of chiefs from political activity by requiring them to refrain from such activity or give up their chieftainships. ${ }^{137}$ Contrary to the recommendation of the Commission, the government determined to restrict the appointment of ministers to members of the National Assembly. ${ }^{138}$ It did accept the recommendation to create a human rights commission and the inclusion of legally non-enforceable principles of state policy in the Constitution. ${ }^{139}$

The most telling of the government responses to the Mwanakatwe Report was the rejection of the Commission's call for a broadly-based Constituent Assembly to ratify proposed constitutional changes. ${ }^{140}$ Rather, the government determined to amend the 1991 Constitution by Act of Parliament, staying away from those provisions relating to fundamental rights, amendments to which would require a referendum.

The government white paper was widely condemned by opposition parties, churches, scholars and students at the universities, members of trade unions, and a

127 Ibid., Chapter 25, 59.

128 Ibid., Chapter 14, 46

129 Ibid., Chapter 20, 54.

130 Ibid., Chapter 8, paragraphs 8.1-8.5, 22.

131 Ibid., Chapter 10, paragraphs 10.0-10.10.

132 Republic of Zambia, Government White Paper, No. 1 of 1995.

133 Ibid., paragraph 13.6.1, 55 (Constitutional Court) and paragraph 12.22, 51 (Electoral Commission).

134 Ibid., paragraph 3.6, 11 .

135 Ibid., paragraph $11.4 .9,38$.

136 Ibid., paragraph $11.5,38$.

137 Ibid. The Government White Paper added the proviso that "such Chiefs should abdicate their Chieftaincy before lodging their nomination", paragraph 12.6, 46.

138 Ibid., paragraph 11.19, 43.

139 Ibid., paragraph 8.1, 29.

140 Ibid., paragraph 27.0, 71-73. 
broad section of the Zambian population. Non-governmental organizations and the churches organized what was termed a "citizens' conference" to raise public awareness and elicit public resistance to the government's proposed measures. ${ }^{141}$ Despite the widespread criticism the government proceeded to amend substantially the I991 Constitution through the enactment of the Constitution of Zambia (Amendment) Act, 1996. ${ }^{142}$ Every Part of the 1991 Constitution was repealed and replaced, except Part III, which governs Protection of Fundamental Rights and Freedom of the Individual. Having rejected the Mwanakatwe Commission's recommendation for ratification by a Constituent Assembly, the government in effect created a new Constitution through an Act of Parliament made possible by its overwhelming majority obtained nearly five years earlier and not renewed since that time.

\section{Conclusion: The 1996 Constitution and Building Democratic ORDER}

In $1994 \mathrm{Mwanakatwe}$ wrote of the failure of the MMD to carry through promptly on its 1991 pledge to promote constitutional debate once multi-party politics were firmly re-established. He assigned two reasons for this change in priorities. First was the stark necessity of facing the country's devastating economic problems. Second came the suggestion that "frequent constitutional changes have inevitably a destabilizing effect. ... A constitution by its nature is always a product of compromise."143 He suggested a number of basic constitutional principles which should characterize a modern democracy: the clear separation of legislative, executive and judicial power; the absence of domination of the legislature by the executive; power in an independent judiciary to determine authoritatively the constitutionality of legislative and executive action; and a charter of fundamental rights, constitutionally protected and legally enforceable through individual access to the courts. He concluded:

"In Zambia the new Constitution adopted in 1991 incorporates most of these principles. It is a constitution that can serve the interests of the people for a long time. However, a constitution works efficaciously when it is widely accepted by the people to whom it gives protection. Therefore, a constitution that is not widely accepted cannot serve any useful purpose. Often it is not even worth the paper on which it is written."144

That change came early to the 1991 Constitution is not surprising. Indeed that document, a compromise between UNIP and MMD mediated by the churches, was by that compromise destined for early re-examination. The Mwanakatwe Commission represented that re-examination. Its product and the government's reaction to it 'have been the subject of vigorous debate, such debate only heightening in its intensity following the government's substantial amendment of the Constitution by an Act of

\footnotetext{
141 Citizens' "Green Paper" Summary of Resolutions by the Citizens' Convention on the draft Constitution, 1-10 March, Lusaka, 1996. The conference was an initiative of church organizations and NGOs. The convention was attended by over 257 participants from a cross-section of the Zambian population.

142 The Constitution of Zambia was amended under Act No. 18 of 1996. The constitutional amendments were adopted without the participation of the major opposition party in Parliament, UNIP, whose members walked out of Parliament in protest at the amendments.

143 Mwanakatwe, above, 222.

144 Ibid., 223.
} 
Parliament without any attempt to achieve consensus or compromise. The debate involves both the substance of the changes and the method of their adoption. As to the latter, the Mwanakatwe Commission had strongly recommended adoption of a new constitution by means of a broadly based constituent assembly and its subsequent amendment only with approval by the people through a national referendum.

Resistance to enactment by Parliament of a Constitution in 1991 on the basis of the Mvunga Commission's report stemmed directly from the Commission's association with the government in power and a widespread belief that the Constitution must be a document of consensus. The Mvunga Commission Report recommended the return of multi-party democracy. Opposition to its unilateral enactment by government was led by the MMD. ${ }^{145}$ There is irony in the actions of the MMD in actually doing in 1996 what its opposition had prevented being done by UNIP in 1991, opposition grounded in democratic principle.

There are powerful arguments that the substance of the Constitution of Zambia (Amendment) Act, 1996, is destructive of democratic principles, thus rendering the method of their adoption even more objectionable. The amendments restrict the participation of Zambians in the electoral process in two ways. First is the prohibition of the participation of chiefs in politics. ${ }^{146}$ Second, it is apparent both in Zambia and throughout the international community that the process of constitution-making was dominated by a desire to bar former President Kaunda from standing for the presidency in the 1996 elections. The requirement that a candidate's parents be born in Zambia (at a time when there was no Zambia) ${ }^{147}$ was proposed and promulgated in the light of common knowledge that Kaunda's parents were born in the territory that is now Malawi, though he was born in what is now Zambia. The two-term limitation on service as President introduced in the 1991 Constitution contained a carefully drawn provision that its application was to be only prospective. Elimination of that provision in 1996 is quite evidently aimed at preventing Kaunda from running again. This article is not a brief for the return of Kenneth Kaunda to the office of President. However, it is submitted that manipulation of the nation's basic charter to advance the ambitions of the party in power runs counter to the democratic principles so effectively espoused by MMD in 1991 and which brought legitimacy to its accession to power and world-wide praise of the Zambian achievement.

From independence every Zambian Constitution has provided for a strong executive, a President wielding substantial power. The need for such a presidency has not been challenged effectively. Transformation of the economic life of the country and continuance of the quest for national unity demand no less. Checks on abuse of necessary power, however, are essential if dictatorship is to be avoided. The Constitution must contain those checks, and they must not be removable simply by the action of a Parliament subservient to the wishes of the incumbent President. Nothing is as destructive of public confidence in the process of government than manipulation of the Constitution for transparently partisan political purposes. Essential

145 Ibid., 215-222.

146 The Constitution of Zambia (as amended by Act No. 18 of 1996), art. 65(3) (4).

147 Citizenship of Zambia was created by article 3(1) in the 1964 Constitution in these terms: "Every person who having been born in the former Protectorate of Northern Rhodesia, is on 23rd October, 1964, a British Protected person shall become a citizen of Zambia on 24 October, 1994". 
too is the fairness of the electoral process itself. From independence every Constitution of Zambia has contained provisions for an Electoral Commission detailed by act of Parliament and appointed by the President. ${ }^{148}$ The 1996 Constitution describes this Commission as "autonomous". ${ }^{49}$ Its autonomy and impartiality must exist and must be seen to exist. Again, manipulation for partisan purposes strikes a severe blow to the Constitution itself. The Mwanakatwe Commission recommended that the presidential appointment of members of the Commission be subject to ratification by a two-thirds vote of the National Assembly and that the tenure of members of the Commission be seven years, all in the interests of that necessary independence. ${ }^{150}$ The rejection of those recommendations by government is ominous.

A constitution conferring great powers needs express limitations on the exercise thereof: hence the necessity for a Bill of Rights enforceable by an independent judiciary. The Constitutions of Zambia have contained detailed provisions relative to "Protection of Fundamental Rights and Freedoms of the Individual". These have been and remain flawed through the presence of "savings clauses", exceptions to each of the enumerated rights, exceptions conferring wide executive and legislative discretion.

Two fundamental rights need emphasis: freedom of the press and freedom from discrimination, particularly against women. Although the present Constitution makes reference to freedom of the press, the powers to derogate therefrom are sweeping. ${ }^{151}$ Constitutional provisions proscribing sex discrimination are confined to enumerated areas and do not address the injustices inflicted through application of aspects of customary law. ${ }^{152}$ It is significant that the government rejected recommendations of the Mwanakatwe Commission dealing with the rights of women. It also rejected the moderate reductions recommended in the exceptions to other fundamental rights.

One additional flaw in the 1996 Constitution should be noted. Against the recommendation of the Mwanakatwe Commission and over the objections of many of the churches, the government inserted in the preamble a provision to "declare the Republic a Christian Nation while upholding the right of every person to enjoy that person's freedom of conscience or religion". The concept of a preferred religion is antithetical to the equality of the people regarding their religious beliefs.

To some the lesson to be drawn from the current constitutional troubles is that Zambia is not ready for a democratic form of government, or perhaps better put, that Western-style democracy is not suitable for the people of that part of Africa called Zambia. We subscribe to neither. One can only begin to make progress from where one is; the past is indeed the prologue. As stated earlier, history cannot be repealed. Whatever the accomplishments, the mistakes, the experiences along the

148 See Constitution of Zambia, 1964, art. 67; Constitution of Zambia, 1973, art. 73(1); Constitution of Zambia, 1991, art. 76.

149 The Constitution of Zambia (as amended by Act No. 18 of 1996), art. 76.

150 Report of the Constitutional Review Commission, above, Chapter 12, paragraph 12.21.1, 39.

151 The Constitution of Zambia (as amended by Act No. 18 of 1996), art. 20(3)(a)(b)(c).

152 Art. 23 makes exceptions to which the prohibition against discrimination does not apply. As a result it does not apply to matters relating to taxation; it is inapplicable to non-citizens and with respect to matters relating to adoption, marriage, divorce, burial, devolution of property on death or other matters of personal law. Most importantly, it is inapplicable in the case of members of a particular race or tribe, to customary law "with respect to any matter to the exclusion of any law with respect to that matter which is applicable in the case of other persons". 
way, after 32 years Zambia remains committed to a republican form of government, to government based on the consent of the governed, in short to democracy.

A constitution should set forth the basic postulates of a free society. This means establishing the basic structure of government, its divisions of powers and limitations on the exercise of those powers. It is a legacy of the colonial period that Zambia's Constitutions have been far too detailed. The British orders-in-council, readily amended to meet problems of the moment, were designed for the conduct of a protectorate, not as structures of an independent sovereign nation. That there are provisions in the Zambian Constitution which ought to be alterable by ordinary legislation means that they do not belong there. We hope that the next constitutional exercise will take this into account. If the contents of the Constitution are truly fundamental, the unalterability of their provisions by ordinary legislation becomes easier to defend. And defended it must be.

The enactment of a constitution, or the making of sweeping amendments in one already in place, involves a number of stages. Thrice Zambia has turned to the Constitutional Commission as the originating device. A salutary aspect in each instance has been a thorough canvassing of views throughout Zambia and a detailed summation of the views expressed. A danger lies in the actual or perceived domination of such commissions by the party in power. Since the "referendum to end referenda" in 1969, every constitutional change in Zambia has been effected by an Act of Parliament. It is here that change is imperative. Whether the initial proposal comes from a constitutional review commission, a constituent assembly or a convention adequately staffed with experts, however the process is originated, its execution must be through a procedure which maximizes the achievement of as broad a national consensus as possible. Action by an extraordinary majority in Parliament is one appropriate step. If it teaches nothing else, painful experience demonstrates that it cannot be the only step. The constituent assembly and the referendum are devices which can be neglected no longer. 